\title{
EDUKASI ANTI BULLYING BAGI GURU DAN SISWA SMP MUHAMMADIYAH BUTUH PURWOREJO
}

\author{
Titik Ulfatun 1), Winda Pratiwi Santosa'), Firsty Presganachya'), Clarisa Ayu Zsa-Zsadilla1) \\ 1)Program Studi Pendidikan Akuntansi, Fakultas Keguruan dan IImu Pendidikan, Universitas Muhammadiyah Surakarta, \\ Surakarta, Jawa Tengah, Indonesia \\ Corresponding author : Titik Ulfatun \\ E-mail : titik.ulfatun@ums.ac.id
}

Diterima 01 Maret 2021, Direvisi 17 Maret 2021, Disetujui 18 Maret 2021

\begin{abstract}
ABSTRAK
Bullying merupakan salah satu permasalahan yang serius bagi anak-anak usia sekolah di berbagai negara, termasuk Indonesia. Salah satu kasus bullying yang terjadi adalah kasus bullying di SMP Muhammadiyah Butuh, Purworejo pada awal tahun 2020. Tujuan kegiatan pengabdian masyarakat ini yaitu untuk meningkatkan pengetahuan dan pemahaman tentang bullying bagi guru dan siswa SMP Muhammadiyah Butuh, Purworejo. Kegiatan ini dilakukan dalam bentuk edukasi bagi guru dan siswa berupa penyampaian materi yang berkaitan dengan bullying, tanya jawab dengan seorang konselor, dan pemberian media edukasi anti bullying berupa poster dan banner. Mereka juga mengerjakan pretest dan post-test. Hasil post-test menunjukkan bahwa guru dan siswa mengalami peningkatan pengetahuan terhadap bullying. Walaupun demikian, peningkatan pengetahuan tersebut tidak signifikan. Kegiatan edukasi serupa sebaiknya dapat dilaksanakan dengan memasukkan tidak hanya aspek pengetahuan saja tetapi juga aspek keterampilan yang berkaitan dengan bullying.
\end{abstract}

Kata kunci: anti bullying; kegiatan edukasi; siswa; guru; sekolah.

\begin{abstract}
Bullying is one of the crucial problems for schoolchildren around the world, including in Indonesia. One of the bullying cases that happened was the bullying case in SMP Muhammadiyah Butuh, Purworejo at the beginning of 2020. This community service program aims to improve the knowledge and understanding of bullying of teachers and students in SMP Muhammadiyah Butuh, Purworejo. This program was an educational program for teachers and students by giving them a lecture, question and answer with a counselor, and giving them an anti-bullying poster and banner. Also, they took the pretest and post-test. The result of the post-test showed that there was a knowledge increase in bullying. However, the increase was not significant enough. A similar program should be done by including not only the knowledge aspect but also the abilities aspect regarding bullying.
\end{abstract}

Keywords: anti-bullying; education program; students; teacher; school.

\section{PENDAHULUAN}

Tindakan bullying merupakan salah satu permasalahan serius yang pada umumnya dihadapi oleh anak-anak dan remaja di berbagai belahan dunia, tak terkecuali di Indonesia. United Nations Educational, Scientific, and Cultural Organization/ UNESCO (2019) sendiri mendefinisikan bullying sebagai perilaku agresif yang melibatkan tindakan negatif yang tidak diinginkan, dilakukan ulang secara terus menerus, dan adanya ketidakseimbangan daya dan kekuatan antara pelaku atau para pelaku dan korban. Dalam laporannya, UNESCO menyebutkan bahwa hampir satu dari tiga siswa atau sekitar $32 \%$ telah mengalami bullying di sekolah yang dilakukan oleh teman-teman sekolahnya paling tidak sekali dalam sebulan terakhir. Lebih dari satu dari tiga siswa $(36 \%)$ telah terlibat dalam perkelahian fisik dengan siswa lain dan hampir satu dari tiga siswa (32.4\%) pernah diserang paling tidak sekali dalam setahun terakhir (UNESCO, 2019).

Kondisi bullying yang terjadi di Indonesia pun tidak jauh berbeda, bahkan persentase siswa yang mengalami bullying lebih tinggi dibandingkan persentase secara keseluruhan yang dituliskan dalam laporan UNESCO sebelumnya. Menurut data hasil riset PISA (Programme for International Students Asessment) pada tahun 2018, Indonesia sendiri menempati urutan tertinggi kelima di dunia dengan jumlah murid yang mengalami bullying yaitu sebesar $41,1 \%$ (Jayani, 2019). Lebih lanjut lagi, Jayani menginformasikan jika dibandingkan dengan persentase rata-rata negara yang tergabung dalam OECD (Organisation for Economic Cooperation and 
Development) yang hanya sebesar $22.7 \%$, maka persentase yang dimiliki Indonesia berada jauh di atas rata-rata. Kasus bullying yang terjadi di sekolah pun dibagi menjadi tingkatan ringan, sedang, dan berat di mana tingkatan ringan dapat berubah menjadi berat ketika pelaku bullying mempunyai rasa sakit hati yang berkepanjangan dan rasa dendam yang berujung pada kematian (Ulfah, Mahmudah, \& Ambarwati, 2017). Tentu saja hal ini merupakan kondisi yang memprihatinkan, yang perlu dicari segera jalan keluarnya di mana kita perlu membasmi bullying hingga ke akar-akarnya.

Penyebab seseorang melakukan bullying beragam. Faktor-faktor yang mempengaruhi seseorang untuk melakukan bullying antara lain faktor keluarga yang bermasalah, sekolah yang abai dengan keberadaan bullying, interaksi dengan teman sebaya yang kadang mendorong untuk melakukan bullying, kondisi lingkungan sosial yang tidak mencukupi, ataupun tayangan televisi dan media cetak yang tidak mendidik (Zakiyah, Humaedi, \& Santoso, 2017). Selain itu, Zakaria (2016) mengungkapkan bahwa penyebab terjadinya bullying dapat dilihat dari tiga komponen utama yaitu korban, pelaku, dan saksi/pengamat. Dia menyebutkan bahwa penyebab dari sisi pelaku diantaranya yaitu pelaku merasa dirinya berkuasa atas korban dan menganggap bullying sebagai perilaku yang wajar dan biasa.

Dampak perilaku bullying tidak hanya dirasakan utamanya oleh para korban tetapi juga oleh pelaku itu sendiri, para saksi dari tindakan bullying, dan semua pihak yang terlibat dalam tindakan bullying. Kementerian Pemberdayaan Perempuan dan Perlindungan Anak/ KPPPA (n.d.) menyatakan bahwa akibat dari bullying bagi korban dapat berupa depresi dan marah, rendahnya tingkat kehadiran dan rendahnya prestasi akademik, serta menurunnya skor tes kecerdasan dan kemampuan analisis siswa. Dampak bagi pelaku bullying jika tidak ada penanganan lebih lanjut maka dapat mengarah pada kekerasan terhadap anak dan bahkan perilaku kriminal. KPPPA (n.d.) juga menjelaskan bahwa tiidak adanya intervensi dapat mengakibatkan para siswa yang menyaksikan bullying beranggapan bahwa bullying adalah hal yang biasa saja dan bisa jadi mereka juga akan bergabung menjadi pelaku bullying. Mengingat buruknya dampak yang dapat ditimbulkan, maka kasus bullying ini merupakan kasus yang perlu untuk ditangani bersama segera.

Pada awal tahun 2020, kasus bullying kembali terjadi di sekolah yaitu tepatnya di SMP Muhammadiyah Butuh, Purworejo (Ramadhan,
2020). Kasus ini menimpa seorang siswi dengan berkebutuhan khusus. Tentu saja hal ini membawa dampak tersendiri baik bagi korban, pelaku, maupun pihak sekolah. Dalam hal ini, pihak sekolah juga turut serta bertanggung jawab atas tindakan bullying tersebut. Sekolah ini pun kemudian sedikit demi sedikit berbenah menjadi sekolah ramah anak/ sekolah anti bullying.

Perwujudan sekolah anti bullying merupakan tanggung jawab warga sekolah bersama, terutama guru, tenaga kependidikan, dan para siswa. Sebagai salah satu langkah awal menuju sekolah anti bullying, maka diperlukan suatu program seperti edukasi kepada warga sekolah tentang bullying. Oleh karena itu, program edukasi anti bullying untuk mendukung sekolah anti bullying di SMP Muhammadiyah Butuh Purworejo merupakan kegiatan yang perlu dilakukan. Sebagaimana yang dikemukakan oleh Prihartono \& Hastuti (2019) bahwa berbagai program seperti pengawasan, penyuluhan, dan pendidikan karakter terbukti efektif dalam pencegahan bullying di sekolah. Selain itu, Saptandari \& Adiyanti (2013) menyatakan bahwa terjadi penurunan kasus bullying yang signifikan setelah sekolah diberikan pelatihan. Kegiatan pengabdian masyarakat ini bertujuan untuk meningkatkan pengetahuan dan pemahaman yang lebih mendalam bagi guru dan siswa tentang bullying sehingga mereka dapat mengaplikasikannya dalam kehidupan sekolah terkait dengan anti bullying.

\section{METODE}

Kegiatan pengabdian masyarakat ini dilaksanakan pada tanggal 30 Januari 2021 dalam bentuk kegiatan edukasi secara langsung kepada tujuh guru dan tujuh siswa di SMP Muhammadiyah Butuh, Purworejo. Terdapat beberapa langkah dalam pelaksanaan kegiatan pengabdian masyarakat ini yaitu:

1. Menghubungi mitra dengan menjelaskan maksud dan tujuan kegiatan pengabdian masyarakat ini, terutama berkaitan dengan permasalahan yang mitra alami yaitu bullying.

2. Melakukan koordinasi dengan mitra mengenai situasi pasca-bullying untuk dapat diketahui intervensi yang dibutuhkan. Koordinasi juga dilakukan berkaitan dengan waktu pelaksanaan kegiatan pengabdian masyarakat.

3. Menghubungi konselor sebagai seorang yang ahli dalam konseling untuk turut serta dalam kegiatan pengabdian masyarakat. 
4. Menyiapkan materi edukasi anti bullying termasuk menyusun pre-test dan post-test, menyusun materi presentasi bagi guru dan siswa, serta mencetak banner dan poster sebagai media edukasi.

5. Melaksanakan kegiatan pengabdian masyarakat pada hari Sabtu, 30 Januari 2021 mulai pukul 09.00 WIB sampai dengan pukul 13.30 WIB.

Kegiatan edukasi bagi guru dan siswa disampaikan melalui penyampaian materi menggunakan PowerPoint . Materi bagi guru meliputi fakta tentang bullying di Indonesia, tips dan trik menghindari dan merespon bullying, dan langkah mencegah bullying di sekolah. Materi bagi siswa meliputi pengertian dan penyebab bullying, jenis-jenis bullying, peran dalam lingkaran bullying, ciri-ciri korban bullying, dampak bullying, bahaya bullying, dan cara mencegah/melawannya.

Berkaitan dengan tujuan kegiatan, pengukuran peningkatan pengetahuan dan pemahaman tentang bullying bagi guru dan siswa dilakukan melalui pre-test dan post-test. Para guru dan siswa mengerjakan pre-test dan post-test sesuai dengan waktu yang telah ditentukan. Bentuk pre-test and post-test bagi guru adalah uraian sedangkan bagi siswa adalah pilihan ganda. Hasil dari pre-test dan post-test lalu dianalisis apakah terjadi peningkatan ataukah tidak.

\section{HASIL DAN PEMBAHASAN}

Hanya Kegiatan pengabdian masyarakat ini secara keseluruhan berjalan dengan baik. Kegiatan edukasi anti bullying ini terdiri dari tiga jenis kegiatan. Pertama, edukasi anti bullying bagi bapak/ibu guru. Total bapak/ibu guru serta tenaga kependidikan yaitu berjumlah 14 orang (guru 12 orang dan tenaga kependidikan 2 orang). Namun, mereka yang hadir pada saat pelaksanaan kegiatan berjumlah 8 orang (guru 7 orang dan 1 ketua komite sekolah). Pada sesi ini dimulai dengan peserta kegiatan, yaitu bapak/ibu guru menerima lembar pre-test untuk diisi berkaitan dengan pengetahuan mereka tentang strategi pencegahan dan penanganan bullying. Selanjutnya, pemberian materi kepada bapak/ibu guru mengenai fakta tentang bullying di Indonesia, tips dan trik menghindari dan merespon bullying, dan langkah mencegah bullying di sekolah. Presentasi ini dilakukan selama \pm 30 menit. Guru memperhatikan dengan saksama materi yang disampaikan (lihat Gambar 1). Kegiatan dilanjutkan dengan tanya jawab bersama konselor. Bapak/ibu guru melakukan tanya jawab serta berbagi cerita bersama konselor secara langsung seputar bullying. Konselor merespon sesuai dengan apa yang bapak/ibu guru utarakan. Dengan adanya sesi tanya jawab bersama konselor ini diharapkan bapak/ibu guru dapat secara langsung mendapatkan respon dari ahlinya berkaitan tentang hal seputar bullying. Sesi tanya jawab bersama konselor berlangsung selama \pm 30 menit. Kegiatan pada sesi ini diakhiri dengan pemberian post-test kepada bapak/ibu guru.

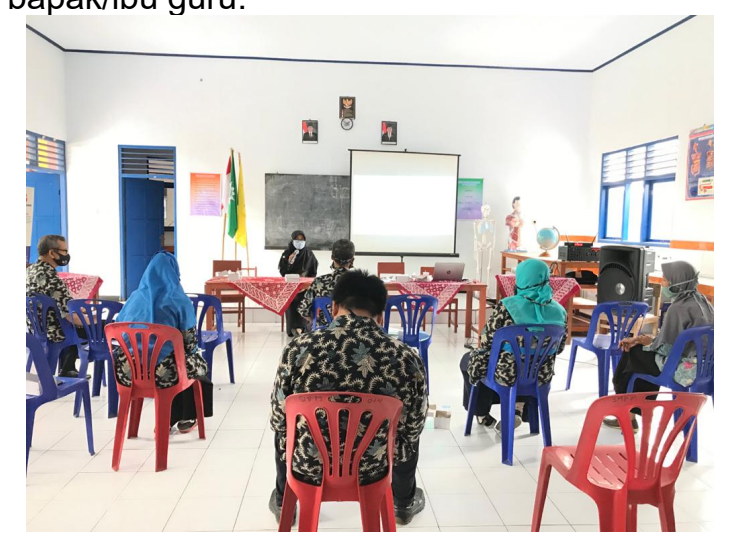

Gambar 1. Bapak/ibu guru mengikuti kegiatan dengan saksama

Kedua, edukasi anti bullying kepada para siswa. Total siswa berjumlah 13 siswa (kelas VII: 3 siswa, kelas VIII: 6 siswa, dan kelas IX: 5 siswa). Namun, mereka yang hadir pada saat pelaksanaan kegiatan berjumlah 7 siswa (kelas VII: 3 siswa dan kelas VIII: 4 siswa). Siswa terlebih dahulu mendapatkan pre-test dan dilanjutkan dengan pemberian materi. Pemberian materi kepada siswa dibagi menjadi dua bagian. Bagian pertama diawali dengan presentasi materi mengenai pengertian dan penyebab bullying, jenis-jenis bullying, peran dalam lingkaran bullying, ciri-ciri korban bullying, dan dampak bullying. Sementara itu, bagian kedua berkaitan dengan materi bahaya bullying dan cara mencegah/melawannya. Presentasi bagian pertama berlangsung dengan tertib dan Inacar selama \pm 15 menit. Siswa memperhatikan dengan baik materi yang disampaikan (lihat Gambar 2). Kegiatan kemudian dilanjutkan dengan ice breaking terlebih dahulu.

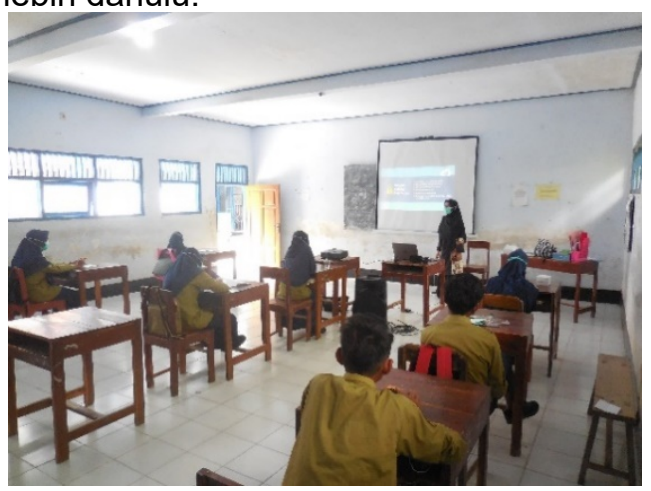

Gambar 2. Siswa memperhatikan presentasi materi tentang bullying 
Ice breaking dilakukan dengan cara siswa menyanyikan lagu Kereta Api dan sembari mereka bernyanyi, mereka juga melakukan estafet spidol. Ketika anggota tim yang memandu berkata "Stop" maka siswa yang memegang spidol terakhir diminta untuk menyebutkan kelebihan dari salah satu teman yang ada di ruangan tersebut. Dengan adanya game ini maka diharapkan siswa dapat melihat potensi positif dari teman-temannya dan dapat memahami temannya dengan lebih baik. Ice breaking dilakukan selama \pm 5 menit.

Kegiatan selanjutnya yaitu review materi bagian pertama mengenai pengertian dan dampak bullying dengan metode card match. Siswa dibagikan kartu yang berisi soal dan jawaban tentang materi tersebut. Masingmasing siswa akan mendapatkan satu kartu yang berisi soal atau jawaban. Selanjutnya, mereka diberikan waktu untuk menjodohkan antara soal dan jawaban tersebut untuk mendapatkan hasil yang benar. Anggota tim yang memandu melakukan pembahasan singkat dari apa yang telah siswa lakukan. Review berlangsung selama \pm 10 menit. Selama kegiatan berlangsung, siswa yang berpartisipasi aktif juga mendapatkan reward berupa hadiah.

Materi bagian kedua yang selanjutnya diberikan kepada siswa yaitu materi tentang bahaya bullying dan cara melawan bullying yang disampaikan dalam waktu \pm 15 menit menggunakan PowerPoint. Selanjutnya, peserta melakukan role play berkaitan dengan materi melawan bullying. Script naskah role play dibagikan kepada lima siswa. Masingmasing siswa menerima dua naskah yaitu script 1 dan script 2. Mereka diminta untuk memperagakan di depan kelas sesuai dengan naskah yang mereka terima. Terdapat perbedaan antara script 1 dan script 2. Dalam script 1 , saksi kejadian bullying bersifat tidak peduli bahkan bersikap sebagai reinforcer, yaitu orang yang cenderung mendukung tindakan bullying seperti menertawakan korban dan memprovokasi pelaku. Dalam script 2, saksi bersikap sebagai defender, yaitu orang yang membela dan membantu korban bully. Mereka diminta untuk mendiskusikan perbedaan tersebut. Hal ini perlu dilakukan mengingat peningkatan intensitas atau kemungkinan berulangnya perilaku bullying pada siswa ternyata dapat dipengaruhi oleh peran orang yang hadir di tempat terjadinya bullying (Halimah, Khumas, \& Zainuddin, 2015). Role play dilakukan selama \pm 15 menit termasuk refleksi. Kegiatan bagi siswa selanjutnya adalah sesi tanya jawab dengan konselor selama \pm 30 menit. Siswa juga menerima lembar post-test pada akhir sesi.
Ketiga, penyerahan media edukasi anti bullying berupa stand-banner dan poster yang berisi informasi umum tentang bullying dan seruan anti bullying. Penyerahan media edukasi dilakukan secara simbolis pada akhir kegiatan (lihat Gambar 3). Terdapat total dua stand-banner dan sepuluh poster yang diserahkan. Media edukasi ini dirasa efektif dalam menyampaikan pesan anti bullying di sekolah.

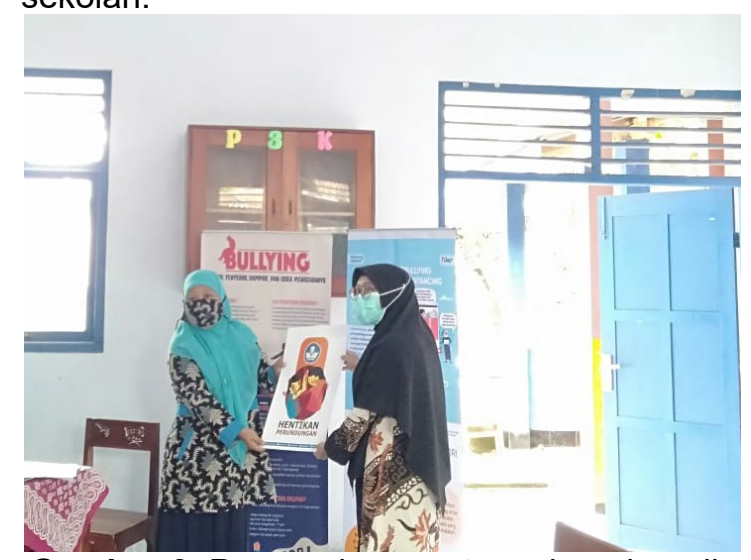

Gambar 3. Penyerahan poster sebagai media edukasi secara simbolis kepada perwakilan sekolah

Guru yang mengikuti pre-test dan posttest berjumlah lima orang. Hal ini dikarenakan dua orang guru masih mempunyai urusan yang lain ketika tes dilaksanakan. Berdasarkan data hasil pre-test dan post-test di atas, dapat diketahui bahwa secara garis besar, terdapat peningkatan pengetahuan dari jawaban yang disampaikan. Jawaban yang mereka sampaikan pada post-test lebih beragam dan sesuai dengan pertanyaan yang disampaikan. Selain itu, jawaban pada post-test dapat lebih melibatkan pada aspek eksternal seperti orangtua/wali siswa dan tenaga profesional dalam kesehatan mental ketika mereka menjawab pertanyaan tentang apa yang harus dilakukan sekolah dalam mencegah bullying.

Berikut adalah tabel perbandingan hasil pre-test dan post-test siswa SMP Muhammadiyah Butuh, Purworejo:

Tabel 1. Hasil pre-test dan post-test siswa

\begin{tabular}{llll}
\hline $\begin{array}{l}\text { Nama } \\
\text { Siswa }\end{array}$ & $\begin{array}{l}\text { Hasil } \\
\text { Pre- } \\
\text { Test }\end{array}$ & $\begin{array}{l}\text { Hasil } \\
\text { Post- } \\
\text { Test }\end{array}$ & Kenaikan \\
\hline Abc & 30 & 40 & $33,33 \%$ \\
Bcd & 70 & 70 & 0 \\
Cde & 60 & 80 & $33,33 \%$ \\
Def & 60 & 60 & 0 \\
Efg & 50 & 50 & 0 \\
Fgh & 50 & 70 & $40 \%$ \\
Ghi & 70 & 80 & $14,29 \%$ \\
Rata-rata & 55,71 & 64,29 & $15,40 \%$ \\
Tertinggi & 70 & 80 & \\
Terendah & 30 & 40 & \\
\hline
\end{tabular}


Berdasarkan Tabel 1, dapat diketahui bahwa secara keseluruhan, terdapat peningkatan rata-rata pengetahuan dari pretest ke post-test sebesar 15,40\%. Persentase kenaikan tersebut bukanlah persentase kenaikan yang signifikan mengingat jika kita melihat kenaikan nilai absolutnya hanya sebesar 8,58 poin. Jika kita melihat pada hasil per individu, tidak semua siswa mengalami peningkatan pengetahuan. Hanya empat siswa yang mengalami peningkatan pengetahun, sedangkan yang tiga lainnya tidak mengalami peningkatan karena nilai yang diperoleh antara pre-test dan post-test adalah sama.

\section{SIMPULAN DAN SARAN}

Kegiatan pengabdian masyarakat ini bertujuan untuk meningkatkan pengetahuan dan pemahaman guru dan siswa mengenai bullying sehingga mereka dapat mengaplikasikannya dalam kehidupan sekolah guna mewujdukan sekolah anti bullying. Kegiatan pengabdian masyarakat ini dilaksanakan dalam bentuk kegiatan edukasi secara langsung kepada guru dan siswa di SMP Muhammadiyah Butuh, Purworejo. Kegiatan pengabdian masyarakat ini berjalan dengan baik. Kegiatan edukasi anti bullying ini terdiri dari tiga jenis kegiatan: edukasi anti bullying bagi bapak/ibu guru; edukasi anti bullying kepada para siswa; dan penyerahan media edukasi anti bullying berupa stand banner dan poster yang berisi informasi umum tentang bullying dan seruan anti bullying. Selain itu, hasil post-test menunjukkan bahwa guru dan siswa mengalami peningkatan pengetahuan terhadap bullying. Berdasarkan hasil kegiatan ini, kegiatan pengabdian masyarakat yang serupa selanjutnya sebaiknya dapat dilaksanakan dengan memasukkan aspek keterampilan yang berkaitan dengan bullying, tidak hanya aspek pengetahuan.

\section{UCAPAN TERIMAKASIH}

Penulis mengucapkan terima kasih kepada Universitas Muhammadiyah Surakarta yang telah mendanai kegiatan pengabdian masyarakat ini.

\section{DAFTAR RUJUKAN}

Halimah, A., Khumas, A., \& Zainuddin, K. (2015). Persepsi pada bystander terhadap intensitas bullying pada siswa SMP. Jurnal Psikologi, 42(2), 129-140. https://doi.org/10.22146/jpsi.7168

Jayani, D. H. (2019). PISA: Murid korban 'bully' di Indonesia tertinggi kelima di dunia. Retrieved from http://databoks.katadata.co.id/datapubl ish/2019/12/12/pisa-murid-korban-

bully-di-indonesia-tertinggi-kelima-didunia

KPPPA. (n.d.). Bullying. Retrieved from https://www.kemenpppa.go.id/lib/uploa ds/list/8e022-januari-ratas-bullyingkpp-pa.pdf

Prihartono, D., \& Hastuti, S. (2019). Sosialisasi penyuluhan stop bullying di SD Negeri 02 Lengkong Wetan Serpong Kota Tangerang Selatan. In Prosiding Seminar Nasional Pengabdian Masyarakat LPPM UMJ (pp. 1-5).

Ramadhan, G. (2020). Siswi SMP korban perundungan di Purworejo penyandang disabilitas. Tirto.ld.

Saptandari, E. W., \& Adiyanti, M. G. (2013). Mengurangi bullying melalui program pelatihan "Guru Peduli." Jurnal Psikologi UGM, 40(2), 193-210. https://doi.org/10.22146/jpsi.6977

Ulfah, W. V., Mahmudah, S., \& Ambarwati, R. M. (2017). Fenomena school bullying yang tak berujung. Intruisi: Jurnal Psikologi Ilmiah, 9(2). https://doi.org/https://doi.org/10.15294/ intuisi.v9i2.11608

UNESCO. (2019). Behind the numbers: Ending school violence and bullying. Paris: United Nations Educational, Scientific and Cultural Organization.

Zakaria, A. F. (2016). Studi tentang upaya guru IPS dalam mengembangkan perilaku prososial dan mengurangi perilaku bullying siswa di SMP. Jurnal Pendidikan Ilmu Sosial, 25(1), 117-124. https://doi.org/https://doi.org/10.17509/ jpis.v25i1.3675

Zakiyah, E. Z., Humaedi, S., \& Santoso, M. B. (2017). Faktor yang mempengaruhi remaja dalam melakukan bullying. Jurnal Penelitian Dan PPPM, 4(2), 129-389. 